\title{
Rare Autoinflammatory Diseases: A Single Center Experience of 47 Patients
}

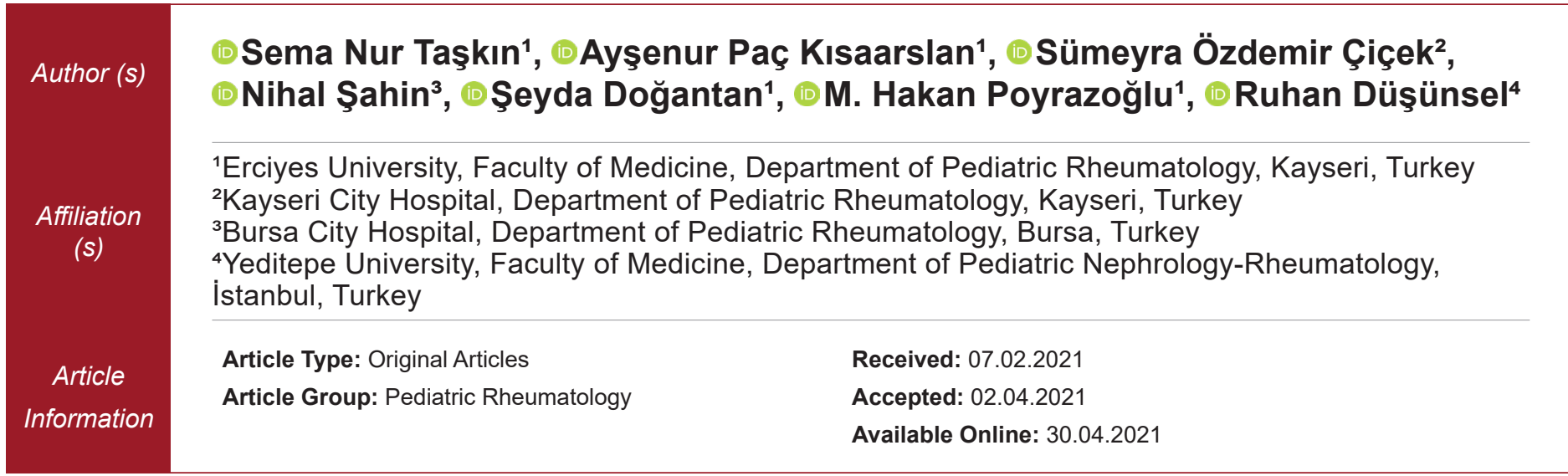

\section{Abstract}

Autoinflammatory diseases include a group disease characterized by recurrent systemic inflammatory attacks due to failure in the regulation of the innate immune system. The beginning time of autoinflammatory disease are the most commonly in childhood. Autoinflammatory disease which having different clinical forms are rare, therefore diagnosis is often delayed. To determine the clinical, laboratory and radiological characteristics of children with rare autoinflammatory diseases and in which patients to consider autoinflammatory disease. Forty seven patients diagnosed with rare autoinflammatory diseases between 2010 and 2020 were analyzed retrospectively. Demographic characteristics, clinical courses, laboratory and imaging findings of the patients were recorded. Forty-seven with rare autoinflammatory patients evaluated. Twenty-three patients had Chronic Nonbacterial Osteomyelitis (CNO), seven patients had Mevalonate Kinase Deficiency (MKD), six patients had Blau Syndrome / Early-Onset Sarcoidosis (BS/EOS) Syndrome, three patients had Cryopyrin-associated periodic fever syndrome (CAPS), three patients had Autoinflammatory Vasculitis, one patient had Sideroblastic anemia with B-cell immunodeficiency, periodic fevers, and developmental delay (SIFD) syndrome, one patient had Neonatal Onset Pancytopenia, Autoinflammation, Rash and Episodic HLH (NOARCH) syndrome. Three of our patients were being followed up with a diagnosis of undiferantiated systemic autoinflammatory disease (uSAID).Autoinflammatory diseases may have different presentations. Steril and recurrent inflammation should be warning clinicians.

Keywords: Rare autoinflammatory diseasea, fever, sterile inflammation, genetics

Correspondence: Muammer Hakan Poyrazoğlu, Division of Pediatric Rheumatology, Department of Pediatrics, Erciyes University Faculty of Medicine, Kayseri, Turkey

E-mail: drpoyrazoglu@yahoo.com 


\section{Introduction}

Autoinflammatory disorders are characterized by recurrent episodes of apparently unprovoked inflammation that, unlike autoimmune disorders, lack the production of high-titer autoantibodies or antigenspecific T cells. ${ }^{1}$ In 1999, the term "Autoinflammatory" was used to denote such a family of clinical disorders. This proposed nomenclature was inspired by the discovery of dominantly-inherited missense mutations in TNFRSF1A, encoding the $55 \mathrm{kDa}$ tumor necrosis factor receptor. ${ }^{2}$ More than 50 new monogenic systemic autoinflammatory diseases (SAID) have been discovered in the last decade with advances in genetics and continues to be discovered. ${ }^{3}$

Familial Mediterranean Fever (FMF) is the most common monogenic autoinflammatory disease, particularly in the Mediterranean. ${ }^{4}$ FMF is characterized by recurrent systemic inflammatory attacks with fever and serositis. Periyodik Ateş, Aftöz Stomatit, Farenjit, Servikal Adenit Sendromu (PFAPA), which not

\section{Highlights}

- Autoinflammatory diseases should come to mind in recurrent fever and sterile inflammations. Diagnosis may be difficult in rare autoinflammatory diseases because of the overlapping clinical findings. The diagnosis is based on genetic investigation. Early diagnosis can shape treatment more accurately and prevent morbidity and mortality.
Blau Syndrome / Early-Onset Sarcoidosis (BS/EOS) Syndrome, three patients had Cryopyrin-associated periodic fever syndrome (CAPS), three patients had Autoinflammatory Vasculitis, one patient had Sideroblastic anemia with B-cell immunodeficiency, periodic fevers, and developmental delay (SIFD) syndrome, one patient had Neonatal Onset Pancytopenia, Autoinflammation, Rash and Episodic HLH (NOARCH) syndrome. Three of our patients were being followed up with a diagnosis of undiferantiated systemic autoinflammatory disease (USAID). known genetic defect still is another SAID wide range of worldwide. Other SAIDs are defined as rare diseases, and more data are need to be shared for a better understanding of rare autoinflammatory diseases.

This study evaluated the demographic, clinical, and laboratory of patients with rare SAIDs in the pediatric rheumatology clinic.

\section{Material and Method}

Patients with autoinflammatory diseases in Erciyes University of Pediatric Rheumatology clinic between January 2010 and January 2020 were evaluated retrospectively. All of the patients were under 18 years of age. Patients with FMF and PFAPA patients were excluded. Demographic, clinic and laboratory data were collected from patients' records with the approval of the local ethics committee of Erciyes University (date:02.12.2020, number: 611).

\section{Statistical Analysis}

All statistical analyses were performed using Statistical Package for the Social Sciences (SPSS) software (IBM SPSS Statistics for Windows, Version 21.0. NY). Continuous variables were shown as mean standard deviation or median [minimum (min)- maximum(max)] and categorical variables are shown using frequency (percentage).

\section{Results}

Forty-seven with rare autoinflammatory patients evaluated. Twenty-three patients had Chronic Nonbacterial Osteomyelitis (CNO), seven patients had Mevalonate Kinase Deficiency (MKD), six patients had

\section{Chronic Nonbacterial Osteomyelitis}

The data of some of the patients included in this study have been published before. ${ }^{5}$ We had 23 CNO patients. Twelve patients $(52.2 \%)$ were male. The mean $\pm S D$ age of patients was $12.8 \pm 4.52$ years. The mean $\pm S D$ age of symptoms onset and diagnosis were $9.5 \pm 4.17$, and $10.4 \pm 4.1$ years, respectively

All patients had
musculoskeletal system complaints. Thirteen patients (56.5\%) had arthralgias, six patients $(26.1 \%)$ had limping, or abnormal gait, three patients $(13.1 \%)$ had local swelling of the bones.

Eleven patients $(47.8 \%)$ had constitutional symptoms, which included fever in $9(81.8 \%)$, malaise in $4(36.4 \%)$, weight loss in 2 patients (18.2\%), and night sweats in 1 patient $(9.1 \%)$. Skin involvement was detected in 5 patients $(21.7 \%)$. None of the patients had a family history of CNO.

Thirteen patients $(56.5 \%)$ had concomitant diseases including FMF in $8, j \mathrm{SpA}$ in 4 patients, psoriatic arthritis in 1 , and IBD in 1 patient. All FMF-CNO patients had at least one M694V variant. Besides, 5 patients had recurrent aphthous stomatitis. But they did not the fulfillment of pediatric Beçet Disease diagnostic criteria. On admission, erythrocyte sedimentation rate (ESR) and C-reactive protein (CRP) levels were high in 16 $(69.6 \%)$ and $13(56.5 \%)$ patients, respectively. Five patients $(21.7 \%)$ had an elevated white blood cell count. Of 18 patients, $3(16.7 \%)$ were positive for human leukocyte antigen (HLA)-B27. Two of these patients had spondyloarthropathy as a concomitant disease.

Regional Magnetic Resonance Imaging (MRI) detected bone lesions in 13, whole-body MRI in 10, and wholebody bone scintigraphy in 8 patients. Regional MRI suggested CNO in 13 patients. This diagnosis was confirmed by whole-body bone scintigraphy in 5 of these 13 patients and whole-body MRI in 3 patients. The most frequently affected areas were femur $(74 \%)$, tibia/fibula $(74 \%)$, and pelvis (52.2\%) (Figure 1). Bone biopsy was performed in seven patients (30.4\%). Biopsy findings showed lymphoplasmacytic cell infiltration consistent with chronic inflammatory osteomyelitis. 


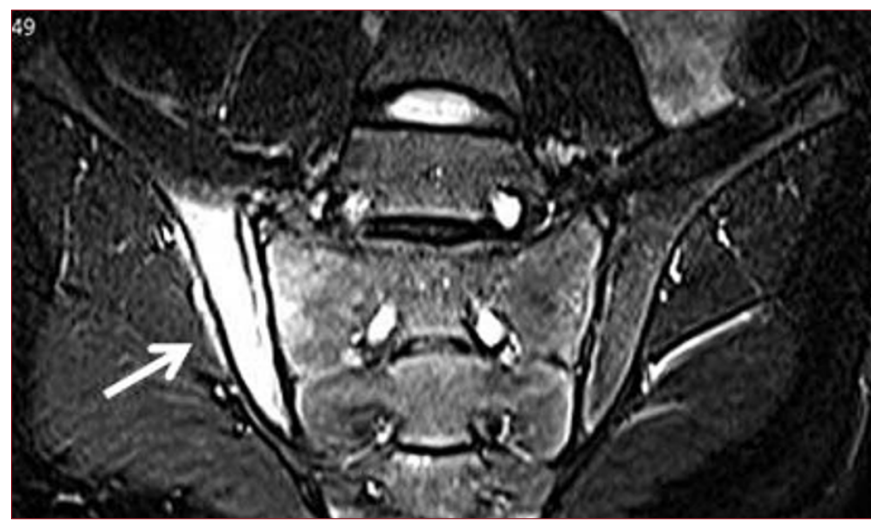

Figure 1. Pelvic MRI of one patient at the diagnosis; T2-weighted turbo spin echo image with fat suppression showing hyperintensity of the right iliac wing.

One patient who was not treated by medication encountered spontaneous complete remission, and radiological findings had disappeared within seven months. Nonsteroidal anti-inflammatory drugs (NSAIDs) were used in 6 (26.1\%), disease-modifying antirheumatic drugs (DMARDs) (methotrexate or sulfasalazine) were used in 13 (56.5\%), biological agents (anti-TNF, IL-1 blocker) were used in $8(34.8 \%)$ patients.

\section{Mevalonate Kinase Deficiency}

We had seven patients diagnosed with MKD. Six (85.7\%) of them were male. The mean $\pm S D$ age of the patients was $12.1 \pm 5,6$ years. The median age of symptoms onset was 5.0 (min:0.3-max:6,1) and the mean diagnosis age was $6.8( \pm 3.4)$ years, respectively.

All patients had a fever, rash, lymphadenopathy (LAP), gastrointestinal system involvement, and high acute phase reactants during the attack. One (14.2\%) patient with amyloidosis had growth retardation.

Arthritis were in 4 (57.1\%), arthralgia was in 6 (85.7\%), oral aphthae was in 4(57.1\%) and conjunctivitis was in $2(28.5 \%)$ patients. Splenomegaly was detected in 3, hepatomegaly was detected in 1 patient. One of our patients had kidney transplantation as a result of amyloid deposition. In genetic analysis, $5(71.4 \%)$ of 7 patients had V377I mutation. Others had not any mutations.

One patient was treated with steroids during attacks. Six of 7 patients were treated with IL-1 blocker, 3 of them were also treated with colchicine.

\section{Blau Syndrome and Early-Onset Sarcoidosis}

The data of some of the patients included in this study have been published before. ${ }^{6}$ There were six patients with the diagnosis of Blau Syndrome / Early Onset Sarcoidosis, including four patients (two men, two women) with EOS and two siblings (one male, one female) with BS. Three $(50 \%)$ of 6 patients were male. The mean \pm SD age of the patients was $12.0 \pm 2.3$ years. The median age of symptoms onset was 1.0 (min:0.3-max:5.0) and the mean diagnosis age was $6.6( \pm 3.2)$ years, respectively.

Five $(83.3 \%)$ of six patients had arthritis, tenosynovitis, camptodactyly, three patients had the rash, two patients had uveitis (Figure 2). Fever was observed in one $(16.6 \%)$ patient. Renal, liver, lung, cranial nervous system involvement, and lymphadenopathy developed in one patient.

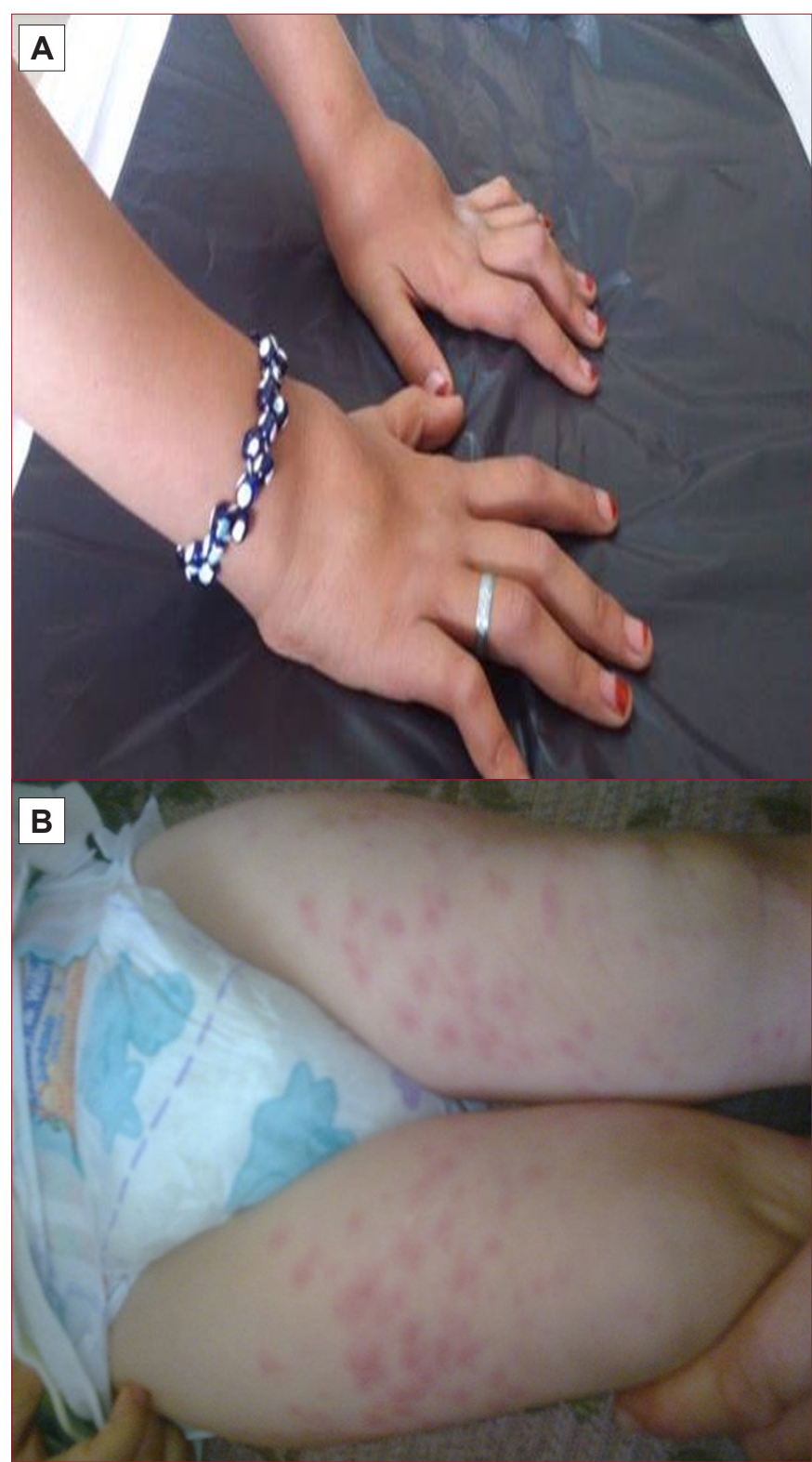

Figure 2. In patients followed up with the diagnosis of Early-Onset Sarcoidosis 2A: Boggy synovid and camptodactyly 2B: Rash

Acute-phase reactant elevation was present in 3 (50\%) patients, and angiotensin-converting enzyme level was elevated in one $(16.6 \%)$ patient.

The mutations were detected as P268S (Exon4), M513T (Exon4), R702W (Exon4), H343Y (Exon4), V955I (Exon4), M491L (Exon4) in patients.

Five patients were treated with methotrexate. Three patients were treated with Tumor necrosis factor $\alpha$ (TNF- $\alpha$ ) inhibitors, one patient was treated with Interleukin-6 Inhibitor, and one of them was treated with tofacitinib.

\section{Cryopyrin-Related Periodic Syndrome}

We had three patients with CAPS. Two (66.6\%) of them were boys. The mean $\pm S D$ age of the patients was $9.4 \pm 2.4$ years. The median age of symptoms onset was 4 (min:1.0-max:4.0) and the mean diagnosis age was 7.3 $( \pm 3.9)$ years, respectively.

All patients had a fever, urticaria-like rash, and high acute phase reactant values at the time of the attack. Two (66.6 $\%)$ patients had arthritis/arthralgia, 2 (66.6 \%) patients had oral aft, $2(66.6 \%)$ patients had gastrointestinal 
involvement, 1 (33.3 \%) patient had eye involvement, 1 (33.3 \%) patient had papilledema, and 1 (33.3 \%) patient had hepatosplenomegaly (Figure 3 ).

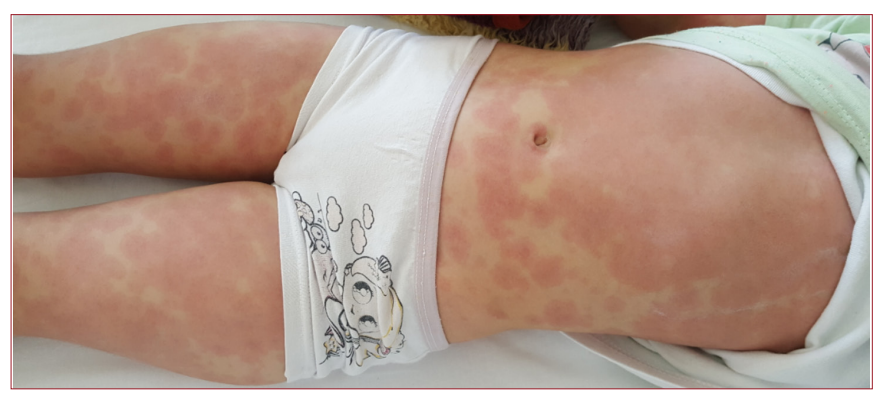

Figure 3. Urticaria-like rash seen in a patient followed up with the diagnosis of Cryopyrin-Related Periodic Syndrome

Two other patients had mutation in the NLRP 3 ((Val198Met(592G>A)) and NLRP12 (p.Thr260Met(c.779C>T)) gene.

Two patients were treated with IL-1 blocker; 1 of them did not receive any medications.

\section{Autoinflammatory Vasculitis}

Three patients were followed up with a diagnosis of autoinflammatory vasculitis. All of the patients were female. The mean $\pm S D$ age of the patients was $11.4 \pm 7.0$ years. The median age of symptoms onset was 2.4 (min:2.4-max:8.0) and the mean diagnosis age was 10.5 $( \pm 6.8)$ years, respectively.

The symptoms of the first patient started at the age of 2.5 years. Fever and seizure were developed during the attacks. Her magnetic resonance imagine findings were appropriated as vasculitis. Hemophagocytic lymphohistiocytosis developed in the follow-up. Her diagnosis was ADA2 deficiency at first, but CECR1 mutation was not detected in the genetic analysis. Her attacks were controlled with Etanercept and steroid therapy.

The attacks of our second patient, whose symptoms started at the age of 2, had a fever, arthritis/arthralgia, and rash. The patient was diagnosed with systemic JIA. During the follow-up, renal involvement and cranial vasculitis were developed. CECR1 mutation was not detected in genetic analysis. This patient also benefited from etanercept and steroid therapy.

The girl who followed by pre-diagnosis of Fanconi anemia had a fever, widespread arthritis, erythema nodosum, and lipodystrophy (Figure). Skin biopsy was compatible with septal panniculitis. The homozygous FANCA mutation (P.Gly1009Asp ) was detected with the wholeexome sequencing. Joint and skin findings improved with etanercept treatment. Bone marrow transplantation was planned for the patient.

\section{Sideroblastic anemia with B-cell immunodeficiency, periodic fevers, and developmental delay}

Patient's symptoms started when she was four months old. The patient was diagnosed at the age of 2 . She had periodicfebrileattacks, anemia, hypogammaglobulinemia, severe growth, and developmental delay. During the attack periods, she had diarrhea and high acute phase reactants. In genetic analysis TRNT1 gene (Exon 6, p.I233fs (c.679 del A, Exon 8 p.K416E (c.126 A>G)) mutation was found. The patient was treated with etanercept and IVIG. Unfortunately, the patient died due to trauma.

\section{Neonatal Onset Pancytopenia, Autoinflammation, Rash and Episodic HLH}

A five-year-old male patient was admitted to the neonatal intensive care unit on the 20th day of age due to anemia, thrombocytopenia, neutropenia, and high acute phase reactants. The patient was diagnosed with septicemia. On the $40^{\text {th }}$ day of age, persistent fever, rash, and hepatosplenomegaly developed. The patient was diagnosed with hemophagocytic lymphohistiocytosis. Anemia, thrombocytopenia, neutropenia, and high acute phase reactants recurred at six months. The patient suffered from mucosal and intracranial bleeding. Anemia and thrombocytopenia regressed, but neutropenia continued in the following years. The patient had hypotonia, mental, motor retardation, and osteoporosis. CDC42 (LRG_1326t1:c556C>T;p Arg186Cys) was detected with whole exon sequencing. The patient was treated with canakinumab and steroid therapy, was also treated with pamidronate therapy for osteoporosis.

\section{Undifferentiated Autoinflammatory Diseases}

There were three patients with a diagnosis of Undifferentiated Autoinflammatory Diseases. 2 (66.6 \%) of them were male. The mean $\pm S D$ age of the patients was $9.3 \pm 8.9$ years. The median age of symptoms onset was 4 (min:0.2-max:17.5) and the mean diagnosis age was $8.4( \pm 8.7)$ years, respectively.

The fever and diarrhea started at seven days old. The patient had lymphadenopathy, psoriatic rashes, and nail dystrophy. His attacks period was longer than a month. STAT5B (p.Arg566GIn(c.1697 G>A)) / TLR6 (Pro740Leu(c.2219 C>T)) mutation was detected in the genetic analysis Interleukin 1 inhibitor, cyclosporine, acitretin treatment was not under controlled the attacks. He was dependent on steroid therapy. Unfortunately, the patient recently died due to Covid 19 at sixteen months.

Our second patient was male, and his symptoms started at the age of 17 . Fever, gastrointestinal symptoms, myalgia, massive pericardial/pleural / peritoneal effusion were observed along with high acute phase reactants during the attack. The familial HLH3 Type 3 related mutation (P.Val731Met(c.2191 G>A) in the UNC13D gene was detected. IL-1 blockade was not effective. His disease was under control with steroid, colchicine, and etanercept therapy.

Six year old female patient's symptoms started at the age of 4 . Fever, gastrointestinal symptoms, myalgia, arthritis/ arthralgia, periorbital edema were observed along with high acute phase reactants during the attacks. NLRP1(p. Met1184Val(c.3550A>G)) mutation was detected .The patient benefited from colchicine and steroid therapy.

The demographic, clinical characteristics, diagnostic methods and treatments of the patients are summarized in Table 1. 


\begin{tabular}{|c|c|c|c|c|c|c|c|c|}
\hline Disease Name & $\mathbf{N}$ & F/M & $\begin{array}{l}\text { The } \\
\text { mean } \pm S D \\
\text { age of } \\
\text { patients } \\
\text { (year) }\end{array}$ & $\begin{array}{c}\text { The } \\
\text { mean } \pm S D \\
\text { age of } \\
\text { symptoms } \\
\text { onset (year) }\end{array}$ & $\begin{array}{l}\text { The } \\
\text { mean } \pm S D \\
\text { age of } \\
\text { symptoms } \\
\text { diagnosis } \\
\text { (year) }\end{array}$ & $\begin{array}{l}\text { Prominent clinical } \\
\text { features }\end{array}$ & $\begin{array}{l}\text { The main } \\
\text { tests to help } \\
\text { diagnose }\end{array}$ & Treatment \\
\hline CRMO & 23 & $11 / 12$ & $12.8 \pm 4.52$ & $9.5 \pm 4.17$ & $10.4 \pm 4.1$ & Localizing bone pain & $\begin{array}{l}\text { MRI, } \\
\text { scintigraphy, } \\
\text { bone biopsy }\end{array}$ & $\begin{array}{l}\text { NSAIDs, DMARDs } \\
\text { or biological agents } \\
\text { (anti-TNF, IL-1 } \\
\text { blocker) }\end{array}$ \\
\hline MKD & 7 & $1 / 6$ & $12.1 \pm 5.6$ & $\begin{array}{l}\text { The median } \\
\text { age:5.0 } \\
\text { (min:0.3- } \\
\text { max:6.1) }\end{array}$ & $6.8 \pm 3.4$ & $\begin{array}{l}\text { Fever, rash, vomiting, } \\
\text { diarrea, LAP, arthritis/ } \\
\text { arthralgia, oral aphthae, } \\
\text { HSM, conjunctivitis, }\end{array}$ & $\begin{array}{l}\text { High AFR } \\
\text { during the } \\
\text { attack, genetic } \\
\text { analysis }\end{array}$ & $\begin{array}{l}\text { Steroid, colchicine, } \\
\text { biological agents } \\
\text { (IL-1 blocker) }\end{array}$ \\
\hline $\begin{array}{l}\text { BLAU Syndrome } \\
\text { /EOS }\end{array}$ & 6 & $3 / 3$ & $12.0 \pm 2.3$ & $\begin{array}{l}\text { The median } \\
\text { age: } 1.0 \\
\text { (min:0.3- } \\
\max : 5.0)\end{array}$ & $6.6( \pm 3.2)$ & $\begin{array}{l}\text { Arthritis, tenosynovitis, } \\
\text { camptodactyly, uveitis, } \\
\text { LAP,fever, rash ,renal, } \\
\text { liver, lung, cranial nervous } \\
\text { system involvement }\end{array}$ & $\begin{array}{l}\text { High AFR } \\
\text { during the } \\
\text { attack, genetic } \\
\text { analysis }\end{array}$ & $\begin{array}{l}\text { DMARDs or } \\
\text { biological agents } \\
\text { (anti-TNF, } \\
\text { Interleukin-1 } \\
\text { and } 6 \text { Inhibitor, } \\
\text { Tofacitinib) }\end{array}$ \\
\hline CAPS & 3 & $1 / 2$ & $9.4 \pm 2.4$ & $\begin{array}{l}\text { The median } \\
\text { age: } 4.0 \\
\text { (min:1.0- } \\
\text { max:4.0) }\end{array}$ & $7.3( \pm 3.9)$ & $\begin{array}{l}\text { Fever, urticaria-like rash, } \\
\text { arthritis/arthralgia, oral aft, } \\
\text { papill edema }\end{array}$ & $\begin{array}{l}\text { High AFR } \\
\text { during the } \\
\text { attack, genetic } \\
\text { analysis }\end{array}$ & $\begin{array}{l}\text { Biological agents } \\
\text { (IL-1 blocker) }\end{array}$ \\
\hline $\begin{array}{l}\text { Autoinflammatory } \\
\text { Vasculitis }\end{array}$ & 3 & 3/- & $11.4 \pm 7.0$ & $\begin{array}{l}\text { The median } \\
\text { age:2.4 } \\
\text { (min:2.4- } \\
\text { max:8.0) }\end{array}$ & $10.5( \pm 6.8)$ & $\begin{array}{c}\text { Fever, seizure, vasculitis, } \\
\text { rash, arthritis/ arthralgia, } \\
\text { erythema nodosum, } \\
\text { lipodystrophy, septal } \\
\text { panniculitis }\end{array}$ & $\begin{array}{l}\text { High AFR } \\
\text { during the } \\
\text { attack, genetic } \\
\text { analysis, MRI, } \\
\text { BMA,skin Bx }\end{array}$ & $\begin{array}{l}\text { Steroid, biological } \\
\text { agents (anti-TNF) }\end{array}$ \\
\hline SIFD & 1 & $1 /-$ & 2.5 & 4 months & 2 & $\begin{array}{l}\text { Fever, GIS involvement, } \\
\text { hypogammaglobulinemia, } \\
\text { severe growth, and } \\
\text { developmental delay. }\end{array}$ & $\begin{array}{l}\text { High AFR } \\
\text { during the } \\
\text { attack, genetic } \\
\text { analysis }\end{array}$ & $\begin{array}{l}\text { Biological agents } \\
\text { (anti-TNF), IVIG }\end{array}$ \\
\hline $\mathrm{NOARCH}$ & 1 & $-/ 1$ & 5 & Neonatal & 6 months & $\begin{array}{l}\text { Fever, rash, pancytopenia, } \\
\text { HLH, HSM, hypotonia, } \\
\text { mental, motor retardation, } \\
\text { osteoporosis }\end{array}$ & $\begin{array}{l}\text { High AFR } \\
\text { during the } \\
\text { attack, genetic } \\
\text { analysis, BMA }\end{array}$ & $\begin{array}{l}\text { Steroid, biological } \\
\text { agents (IL- } \\
1 \text { blocker), } \\
\text { pamidronate }\end{array}$ \\
\hline $\begin{array}{l}\text { Undifferentiated } \\
\text { Autoinflammatory } \\
\text { Diseases }\end{array}$ & 3 & $1 / 2$ & $9.3 \pm 8.9$ & $\begin{array}{l}\text { The median } \\
\text { age:4 } \\
\text { (min: } 0.2- \\
\text { max:17.5) }\end{array}$ & $8.4( \pm 8.7)$ & $\begin{array}{c}\text { Fever,rasch, GIS } \\
\text { involvement,LAP, miyalgia, } \\
\text { serositis, arthritis/ } \\
\text { arthralgia, periorbital } \\
\text { edema }\end{array}$ & $\begin{array}{l}\text { High AFR } \\
\text { during the } \\
\text { attack, genetic } \\
\text { analysis, }\end{array}$ & $\begin{array}{l}\text { Steroid, biological } \\
\text { agents (IL-1 } \\
\text { blocker, anti-TNF), } \\
\text { cyclosporine, } \\
\text { colchicine }\end{array}$ \\
\hline
\end{tabular}

\section{Discussion}

\section{Chronic Nonbacterial Osteomyelitis}

Chronic nonbacterial osteomyelitis is characterized by noninfectious bone inflammation. ${ }^{7}$ It is often referred to as "chronic recurrent osteomyelitis" in cases where multifocal or recurrent features are seen during the clinical course. ${ }^{8}$

It is known that CNO is an autoinflammatory disease and may occur as a result of monogenic diseases such as Majeed syndrome, ${ }^{9}$ deficiency of the IL-1 receptor antagonist (DIRA), ${ }^{10}$ and pyogenic arthritis, Pyoderma gangrenosum, and acne(PAPA syndrome. ${ }^{11,12}$ In most sporadic cases, responsible genes were not found.

Concomitant inflammatory diseases were reported in $30 \%$ of patients with CNO. These diseases mainly involve the skin and intestine. Psoriasis, palmoplantar pustulosis, Crohn disease, ulcerative colitis, celiac disease, and sypondiloarthritis were reported with $\mathrm{CNO}$ patients..$^{13}$ In our observation reported before, FMF was the most common concomitant disease with a rate of $34.8 \%$. All of our FMF-CNO patients had at least one M694V variant. In our experience, the M694V variant may be a predisposing factor of CRMO. ${ }^{5}$

In contrast to a previous report, ${ }^{14}$ the incidence of aphthous stomatitis was higher in our cohort $(21.7 \%$ vs $1 \%$ ). None of our patients had uveitis or symptoms related to Behçet disease. Of 18 patients, $3(16.7 \%)$ were positive for human leukocyte antigen (HLA)-B27, which is not as high as seen in jSpA in Turkish children. ${ }^{15,16}$

Other clinical, laboratory and radiologic findings in our patients were consistent with the literature. ${ }^{13,14,17,18}$

Patients with non-specific musculoskeletal complaints and have localizing bone pain should be evaluated for CRMO. 


\section{Mevalonate Kinase Deficiency}

Mevalonate Kinase Deficiency is an autosomal recessive autoinflammatory disease. It is caused by loss-of-function mutations in the MVK gene that encode mevalonate kinase, a critical enzyme involved in cholesterol biosynthesis. ${ }^{19} \mathrm{~V} 377 \mathrm{I}$ and I268T are the most common pathogenic mutations..$^{20,21}$ These two mutations are located in highly conserved positions of orthologous gene products in human ${ }^{22}$ Most MKD patients are heterozygous for two different variants. ${ }^{21}$ Five (\%71.4) of the 7 patients had V377I mutation in their genetic analysis. The mutation was not detected in two patients.

MKD is characterized by a variable clinical progression, with an episodic-recurrent or chronic pattern, and usually presents with early childhood onset, mostly within the first year of life, but can manifest during the first five years. The occurrence of symptoms after five years of age excludes the diagnosis. ${ }^{23}$ The mean age of onset of symptoms was at 3.5 years. Conversely to the literature, the symptoms started later in our patients.

Acute episodes generally occur every 4-6 weeks and last about 3-7 days on average, with asymptomatic periods between attacks. ${ }^{23}$ Disease severity highly correlates with the mevalonate kinase enzymatic function. ${ }^{24}$ Patients suffer from the episodic high-grade fever that may be accompanied by oral ulcers, cervical lymphadenopathy, gastrointestinal symptoms, skin rashes, arthritis, or headache. ${ }^{23,25} \mathrm{All}$ of our patients had an episodic high-grade fever, rash, lymphadenopathy, gastrointestinal system involvement, and high acute phase reactants during the attack.

Amyloidosis can be seen in about $3 \%$ of cases. ${ }^{23}$ One of our patients had kidney transplantation as a result of amyloid deposition. To our knowledge, it is the first reported case of renal AA amyloidosis, which caused severe nephrotic disease in a Turkish child due to MKD. ${ }^{26}$ His attacks repeated after renal transplantation. The attacks were controled with canakinumab treatment. We considered canakinumab treatment is safe in renal transplantation. ${ }^{27}$

MKD should be considered in fever, cervical lymphadenopathy, abdominal pain, and diarrhea despite symptoms started after the infancy period.

\section{Blau Syndrome and Early-Onset Sarcoidosis}

The clinical triads are granulomatous dermatitis, symmetrical arthritis, and recurrent uveitis that began before four years old. ${ }^{28}$ Blau syndrome is a hereditary form, EOS is a sporodic form of the disease. Two forms of the disease associate with NOD2 mutation. ${ }^{29}$ Our sibling patients and their mother were assessed as BS because of the familial form of the disease.

The disease begins typically before four years of age. ${ }^{29}$ However, symptoms sometimes appear after the age of $10 .^{30}$ Our patients' initial symptoms started at about two years in accordance with the literature.

Two main types of symptomatic eruptions are reported: rash and multiple subcutaneous nodules. ${ }^{31}$ Histology of the lesions demonstrates non-caseating granulomas with multinucleated giant cells. ${ }^{32}$ Our patients' biopsies were shown noncaseating granulomatous inflammation on the kidney, hepatic, lymph node, and dermal biopsy.

Joint manifestations usually appear such as symmetric polyarthritis, and contractures often develop in the PIP joints in the early disease course. These early deformities are described as camptodactyly. ${ }^{33}$ Granulomatous inflammation in the periarticular structures leads to marked periarticular swelling and tenosynovial cysts, which significantly affect the hands' wrists and dorsa. ${ }^{31}$ Rosé et al. reported that the characteristics of arthritis in BS, comprising boggy synovitis and tenosynovitis, are distinct from those observed in JIA. ${ }^{34}$ Our patients' most common manifestations were boggy synovitis and camptodactyly. These clinical findings allowed us to establish an early diagnosis.

Eye symptoms generally appear later at around the age of $12 .{ }^{33}$ Chorioretinitis, cataracts, glaucoma, and retinal detachment can lead to significant visual impairment and blindness. ${ }^{31}$ As a result of regular eye examinations, uveitis was detected in two of our patients, and it was controlled with early treatment.

The most commonly detected NOD2 mutations are R334W and R334Q. ${ }^{35} \mathrm{BS}$ / EOS penetration associated with NOD2 mutations is very high, but asymptomatic family members with NOD2 mutations have also been described in the literature. ${ }^{36-38}$ The father of family patients had a V955I mutation and did not have any symptoms.

BLAU/EOS Syndrome should be considered when joint deformity, bogy synovitis develop at a young age.

\section{Cryopyrin-Associated Periodic Fever Syndrome}

CAPS is an autosomal dominantly inherited disease characterized by attacks of fever, urticaria, arthritis, bone deformity, deafness, and CNS involvement. The mutations in the C1AS1 gene, known as NLRP3, on chromosome 1 are lead to the disease. ${ }^{39,40}$

CAPS is the spectrum disease. The mild form is called familial cold autoinflammatory syndrome (FCAS). The moderate form is called Muckle-Wells syndrome. The severe forms of the spectrum represent chronic infantile neurological cutaneous and articular syndrome (CINCA) or neonatal-onset multisystem inflammatory disease (NOMID). ${ }^{41}$ Two of our three patients were diagnosed with FCAS. One of the patients was diagnosed with FCAS2. FCAS2 develop in patients with NLRP12 variants (FCAS2, OMIM \# 611762). This autosomaldominant disease with a clinical phenotype between FCAS and MWS was reported in several families. ${ }^{42}$ Approximately 62 patients with NLRP12 variants have been reported in the literature so far. ${ }^{43}$

The age of onset of symptoms is expected to be under one year of age. The symptoms onset age is our patients was 4.3 (years). ${ }^{39}$ Diagnostic delay can be seen in patients with the mild phenotype. ${ }^{44}$

Levy et al. reported that the most common symptoms were fever, skin rash, and musculoskeletal involvement (although deforming arthritis is rare) observed in $84 \%$, $97 \%$, and $86 \%$ of patients, respectively. ${ }^{45}$ The clinics 
of our patient, who had cold / stress-triggered attacks, were compatible with the literature.

Papilledema, deafness, seizures, and developmental delay may develop during follow-up. ${ }^{46,47}$ All CAPS patients should evaluated eye and ear examinations regularly. None of the patients had sensorineural hearing loss. One of them had papilla edema during the attack period. It regressed with steroid therapy and not recurred. Eye involvements that threaten vision at any level from the cornea to the optic nerve are common findings. ${ }^{48-50}$

CAPS should be considered in the case of patients with fever, urticarial rash, and high acute phase reactants.

\section{Autoinflammatory Vasculitis}

Vasculitis can also be either one of an autoinflammatory disease's characteristics or highly associated with an autoinflammatory disease ${ }^{49,50}$ It is known that FMF is accompanied by vasculitides such as IgA vasculitis, polyarteritis nodosa, and Behçet's disease..$^{51}$

The Autoinflammatory vasculitides were listed as Deficiency of Adenosine Deaminase 2 (DADA2), STING-associated vasculopathy with onset in infancy (SAVI), and COPA Syndrome. DADA2 usually manifests as a PAN-like disease with recurrent stroke, livedoid skin rash, and immunodeficiency features. SAVI is an autoinflammatory vasculopathy with causing severe skin lesions that cause ulceration, necrosis, and in some cases amputation. Copa Syndrome features include erosive polyarthritis, an interstitial lung disease with or without pulmonary hemorrhage, and kidney disease with autoantibodies (ANA, ANCA, RF, and others). ${ }^{52,53}$

Our first two patients were compatible with the DADA2 clinic. It is known that etanercept treatment is effective in patients with a vasculitic form of DADA2. Both patients are under control with etanercept treatment. We follow these patients with genetically negative DADA2 diagnosis. The last patient was also evaluated as DADA2 with hematological involvement, but homozygous FANCA mutation was detected in WES analysis. The sweet syndrome was reported in FA with malignancy. ${ }^{54,55}$ In our patient, malignancy was not detected in the 1.5-year follow-up, and bone marrow transplantation was planned.

\section{Sideroblastic anemia with B-cell immunodeficiency, periodic fevers, and developmental delay Syndrome}

Mutations in the gene encoding transfer RNA (tRNA) nucleotidyltransferase (TRNT1) are associated with SIFD syndrome. Knockdown of TRNT1 results in significant cytotoxicity and apoptosis. ${ }^{56}$ Approximately 30 patients with TRNT1 deficiency have been identified in the literature with significant heterogeneity in the clinical phenotype and underlying immunological defects. ${ }^{57}$ Our patient's anemia was not sideroblastic anemia. Other findings were consistent with classical SIFD findings. The diagnosis of the patient was made by whole-exome sequencing (WES). The importance of WES in undifferentiated autoinflammatory diseases is increasingly accepted. ${ }^{58}$

\section{Neonatal Onset Pancytopenia, Autoinflammation, Rash and Episodic HLH}

Hemophagocytic lymphohistiocytosis (HLH) has characterized by hyperinflammation due to overactivation and expansion of macrophages and CD8+ T lymphocytes. ${ }^{59,60}$ Cell division cycle 42 (CDC42) is a member of the Ras- homologous (Rho) GTPase family functioning as a signaling node controlling several cellular processes, including adhesion, migration, polarity, cell cycle, and proliferation. ${ }^{61} \mathrm{NOARCH}$ syndrome, which developed due to aberrant CDC42 function, was newly described in 4 patients in 2019 as neonatal-onset pancytopenia, autoinflammation, rash, and episodic HLH. ${ }^{62}$ Our patient was diagnosed with WES at the age of 5 . This shows once again the importance of genetic analysis.

\section{Undifferentiated Autoinflammatory Diseases}

The number of innate immune system disorders classified as systemic autoinflammatory diseases (SAID) has increased in recent years. More than 70-80 $\%$ of patients with clinical signs of SAID did not receive a molecular diagnosis and were therefore classified as undifferentiated SAID. ${ }^{58}$

In 2019, the Euro fever Project described the characteristics of 187 patients with uSAIDs, concluding a need for new classification criteria for monogenic SAIDs. It was stated that more research is needed to provide insight into the genetic and clinical relationship and the genotype-phenotype connection. ${ }^{63}$

Our first patient was diagnosed with DITRA. But bone pathology was not detected. Beyond this, genetic analysis was not appropriate with the DITRA. It has been determined that STAT5B deficiency affects growth, especially $T$ regulatory cell deficiency. ${ }^{64}$ Tolllike receptors (TLRs) have been shown to play a role in the innate immune response, and constitutively active TLR6 activates both NF-kB and c-Jun N-terminal kinase (JNK) ${ }^{65}$ Both two mutations could be affected by the severe disease course in our patients.

HLH3 mutation was detected in the second patient. Feldmann et al. identified a Familial Hemophagocytic Lymphohistiocytosis (FHL) subtype, FHL3, in 10 patients from 7 unrelated families. ${ }^{66}$ We diagnosed the patient as uSAID, because clinical and laboratory findings did not appropriate the HLH.

NLRP1 inflammasome is effective in converting interleukin-1 $\beta$ and interleukin-18 into the active forms. ${ }^{67}$ The patient's clinic was not compatible with a specific autoinflammatory disease. But he responded to colchicine therapy. We reported this patient at ISSAID congress in 2019. ${ }^{68}$

\section{Conclusion}

Autoinflammatory diseases may have different presentations. Steril and recurrent inflammation should be a warning to clinicians. New developments in genetics facilitate the diagnosis of autoinflammatory diseases. 
Author Contributions: All of the authors declare that they have all participated in the design, execution, and analysis of the paper, and that they have approved the final version.

Conflict of Interest: The authors have no conflict of interest to declare.

Ethics Committee Approval: Ethical approval of Erciyes University Faculty of Medicine Ethics Committee was obtained for this study (date:02.12.2020, number: 611).

Financial Disclosure: There is no financial disclosure to be declared

Informed Consent: Informed consent form was filled out by parents and their consents were obtained.

\section{References}

1. Galon J, Aksentijevich I, McDermott MF, O'Shea JJ, Kastner DL. TNFRSF1A mutations and autoinflammatory syndromes. Curr Opin Immunol. 2000;12:479-486. [CrossRef]

2. McDermott MF, Aksentijevich I, Galon J, et al. Germline mutations in the extracellular domains of the $55 \mathrm{kDa}$ TNF receptor, TNFR1, define a family of dominantly inherited autoinflammatory syndromes. Cell. 1999;97:133-144. [CrossRef]

3. Georgin-Lavialle S, Ducharme-Benard S, Sarrabay G, Savey L, Grateau G, Hentgen V. Systemic autoinflammatory diseases: Clinical state of the art. Best Pract Res Clin Rheumatol. 2020;34:101529. [CrossRef]

4. Marino A, Tirelli F, Giani T, Cimaz R. Periodic fever syndromes and the autoinflammatory diseases (AIDs). J Transl Autoimmun. 2019;3:100031. [CrossRef]

5. Çiçek SÖ, Şahin N, Karaman ZF, et al. The Possible Relationship Between Familial Mediterranean Fever and Chronic Nonbacterial Osteomyelitis: Coincidence or Coexistence? J Clin Rheumatol. 2020;10.1097/RHU.0000000000001431. [CrossRef]

6. PaÇ Kisaarslan A, SÖzeri B, Şahỉn N, et al. Blau Syndrome and Early-Onset Sarcoidosis: A Six Case Series and Review of the Literature. Arch Rheumatol. 2019;35:117-127. [CrossRef]

7. Giedion A, Holthusen W, Masel LF, Vischer D. [Subacute and chronic "symmetrical" osteomyelitis]. Ann Radiol (Paris). 1972;15:329-342.

8. Morbach H, Hedrich CM, Beer M, Girschick HJ. Autoinflammatory bone disorders. Clin Immunol. 2013;147:185-196. [CrossRef]

9. Majeed HA, Kalaawi M, Mohanty D, etal. Congenital dyserythropoietic anemia and chronic recurrent multifocal osteomyelitis in three related children and the association with Sweet syndrome in two siblings. J Pediatr. 1989;115:730-734. [CrossRef]

10. Aksentijevich I, Masters SL, Ferguson PJ, et al. An autoinflammatory disease with deficiency of the interleukin-1-receptor antagonist. $N$ Engl J Med 2009; 360:2426-2437. [CrossRef]

11. Lindor NM, Arsenault TM, Solomon H, Seidman CE, McEvoy MT. A new autosomal dominant disorder of pyogenic sterile arthritis pyoderma gangrenosum, and acne: PAPA syndrome. Mayo Clin Proc. 1997;72:611-615. [CrossRef]

12. Smith EJ, Allantaz F, Bennett L, et al. Clinical, Molecular, and Genetic Characteristics of PAPA Syndrome: A Review. Curr Genomics. 2010;11:519-527. [CrossRef]

13. Jansson A, Renner ED, Ramser J, et al. Classification of nonbacterial osteitis: retrospective study of clinical, immunological and genetic aspects in 89 patients. Rheumatology (Oxford). 2007;46:154-160. [CrossRef]

14. Girschick H, Finetti M, Orlando F, et al. The multifaceted presentation of chronic recurrent multifocal osteomyelitis: a series of 486 cases from the Eurofever international registry. Rheumatology (Oxford). 2018;57:1203-1211. [CrossRef]

15. Kısaarslan AP, Sözeri B, Gündüz Z, Zararsız G, Poyrazoğlu $H$, Düşünsel R. Evaluation of factors affecting the duration of disease-modifying anti-rheumatic drugs application in patients with enthesitis-related arthritis. Eur J Rheumatol. 2019;6:130-135. [CrossRef]
16. Demirkaya E, Ozen S, Bilginer $Y$, et al. The distribution of juvenile idiopathic arthritis in the eastern Mediterranean: results from the registry of the Turkish Paediatric Rheumatology Association. Clin Exp Rheumatol. 2011;29:111-116. [CrossRef]

17. Kaiser D, Bolt I, Hofer M, et al. Chronic nonbacterial osteomyelitis in children: a retrospective multicenter study. Pediatr Rheumatol Online J. 2015;13:25. [CrossRef]

18. Beck C, Morbach $H$, Beer $M$, et al. Chronic nonbacterial osteomyelitis in childhood: prospective follow-up during the first year of anti-inflammatory treatment. Arthritis Res Ther. 2010;12:R74. [CrossRef]

19. Prasad C, Salvadori MI, Rupar CA. Severe phenotypic spectrum of mevalonate kinase deficiency with minimal mevalonic aciduria. Mol Genet Metab. 2012;107:756-759. [CrossRef]

20. Pepper RJ, Lachmann HJ. Autoinflammatory Syndromes in Children. Indian J Pediatr. 2016;83:242-247. [CrossRef]

21. Figueras-Nart I, Mascaró JM Jr, Solanich X, Hernández-Rodríguez $\mathrm{J}$. Dermatologic and Dermatopathologic Features of Monogenic Autoinflammatory Diseases. Front Immunol. 2019;10:2448. [CrossRef]

22. Drenth JP, Cuisset L, Grateau G, et al. Mutations in the gene encoding mevalonate kinase cause hyper-lgD and periodic fever syndrome. International Hyper-IgD Study Group. Nat Genet. 1999;22:178-181. [CrossRef]

23. Caso F, Rigante D, Vitale A, et al. Monogenic autoinflammatory syndromes: state of the art on genetic, clinical, and therapeutic issues. Int J Rheumatol. 2013;2013:513782. [CrossRef]

24. Simon A, van der Meer JW. Pathogenesis of familial periodic fever syndromes or hereditary autoinflammatory syndromes. Am J Physiol Regul Integr Comp Physiol. 2007;292:R86-R98. [CrossRef]

25. Jeyaratnam J, Frenkel J. Management of Mevalonate Kinase Deficiency: A Pediatric Perspective. Front Immunol. 2020;11:1150. [CrossRef]

26. Yel S, Gunduz Z, Bastug F, et al. Amyloidosis in a child with hyperimmunoglobulinemia D syndrome. Iran $J$ Kidney Dis. 2013;7:70-72. [CrossRef]

27. Dursun I, Sözeri B, Paç Kısaarslan A, et al. Canakinumab is safe in the treatment of renal transplant patient having amyloidosis secondary to hyper. Ig-D syndrome; Proceedings of the 23rd Paediatric Rheumatology European Society Congress: part one: Genoa, Italy. 28 September-01 October 2016. Pediatr Rheumatol Online J. 2017;15:37. [CrossRef]

28. Blau EB. Familial granulomatous arthritis, iritis, and rash. J Pediatr. 1985;107:689-693. [CrossRef]

29. Becker ML, Rose CD. Blau syndrome and related genetic disorders causing childhood arthritis. Curr Rheumatol Rep. 2005;7:427-433. [CrossRef]

30. Milman N, Ursin K, Rødevand E, Nielsen FC, Hansen TV. A novel mutation in the NOD2 gene associated with Blau syndrome: a Norwegian family with four affected members. Scand J Rheumatol. 2009;38:190-197. [CrossRef]

31. Sfriso P, Caso F, Tognon S, Galozzi P, Gava A, Punzi L. Blau syndrome, clinical and genetic aspects. Autoimmun Rev. 2012;12:44-51. [CrossRef]

32. Alonso D, Elgart GW, Schachner LA. Blau syndrome: a new kindred. J Am Acad Dermatol. 2003;49:299-302. [CrossRef]

33. Wouters $\mathrm{CH}$, Maes A, Foley KP, Bertin J, Rose CD. Blau syndrome, the prototypic auto-inflammatory granulomatous disease. Pediatr Rheumatol Online J. 2014;12:33. [CrossRef]

34. Rosé CD, Pans S, Casteels I, et al. Blau syndrome: crosssectional data from a multicentre study of clinical, radiological and functional outcomes. Rheumatology (Oxford). 2015;54:10081016. [CrossRef]

35. Rosé CD, Aróstegui JI, Martin TM, et al. NOD2-associated pediatric granulomatous arthritis, an expanding phenotype: study of an international registry and a national cohort in Spain. Arthritis Rheum. 2009;60:1797-1803. [CrossRef]

36. Galozzi P, Negm O, Greco E, et al. Ex vivo and in vitro production of pro-inflammatory cytokines in Blau syndrome. Reumatismo. 2015;66:277-284. [CrossRef]

37. Ebrahimiadib N, Samra KA, Domina AM, et al. A Novel NOD2associated Mutation and Variant Blau Syndrome: Phenotype and Molecular Analysis. Ocul Immunol Inflamm. 2018;26:57-64. [CrossRef] 
38. Saulsbury FT, Wouters CH, Martin TM, et al. Incomplete penetrance of the NOD2 E383K substitution among members of a pediatric granulomatous arthritis pedigree. Arthritis Rheum. 2009;60:18041806. [CrossRef]

39. Ozen S. What's new in autoinflammation?. Pediatr Nephrol. 2019;34:2449-2456. [CrossRef]

40. Navallas $\mathrm{M}$, Inarejos Clemente EJ, Iglesias E, Rebollo-Polo M, Zaki FM, Navarro OM. Autoinflammatory diseases in childhood, part 1: monogenic syndromes. Pediatr Radiol. 2020;50:415-430. [CrossRef]

41. Federici S, Vanoni F, Ben-Chetrit E, et al. An International Delphi Survey for the Definition of New Classification Criteria for Familial Mediterranean Fever, Mevalonate Kinase Deficiency, TNF Receptor-associated Periodic Fever Syndromes, and Cryopyrinassociated Periodic Syndrome. J Rheumatol. 2019;46:429-436. [CrossRef]

42. Hashkes PJ, Toker O. Autoinflammatory syndromes. Pediatr Clin North Am. 2012;59:447-470. [CrossRef]

43. Del Porto F, Cifani N, Proietta M, et al. NLRP12 gene mutations and auto-inflammatory diseases: ever-changing evidence. Rheumatology (Oxford). 2020;59:3129-3136. [CrossRef]

44. Mehr S, Allen R, Boros C, et al. Cryopyrin-associated periodic syndrome in Australian children and adults: Epidemiological, clinical and treatment characteristics. J Paediatr Child Health. 2016;52:889895. [CrossRef]

45. Levy R, Gérard L, Kuemmerle-Deschner J, et al. Phenotypic and genotypic characteristics of cryopyrin-associated periodic syndrome: a series of 136 patients from the Eurofever Registry. Ann Rheum Dis. 2015;74:2043-2049. [CrossRef]

46. Caorsi R, Lepore L, Zulian F, et al. The schedule of administration of canakinumab in cryopyrin associated periodic syndrome is driven by the phenotype severity rather than the age. Arthritis Res Ther. 2013;15:R33. [CrossRef]

47. Posch C, Kaulfersch W, Rappersberger K. Cryopyrin-associated periodic syndrome. Pediatr Dermatol. 2014;31:228-231. [CrossRef]

48. Keddie S, Parker T, Lachmann HJ, Ginsberg L. CryopyrinAssociated Periodic Fever Syndrome and the Nervous System. Curr Treat Options Neurol. 2018;20:43. [CrossRef]

49. Peleg H, Ben-Chetrit E. Vasculitis in the autoinflammatory diseases. Curr Opin Rheumatol. 2017;29:4-11. [CrossRef]

50. Ginsberg S, Rosner I, Rozenbaum M, et al. Autoinflammatory associated vasculitis. Semin Arthritis Rheum. 2016;46:367-371. [CrossRef]

51. Abbara S, Grateau G, Ducharme-Bénard S, Saadoun D, GeorginLavialle S. Association of Vasculitis and Familial Mediterranean Fever. Front Immunol. 2019;10:763. [CrossRef]

52. Demir S, Sag E, Dedeoglu F, Ozen S. Vasculitis in Systemic Autoinflammatory Diseases. Front Pediatr. 2018;6:377. [CrossRef]

53. Pathak S, McDermott MF, Savic S. Autoinflammatory diseases: update on classification diagnosis and management. J Clin Pathol. 2017;70:1-8. [CrossRef]
54. Giulino L, Guinan EC, Gillio AP, Drachtman RA, Teruya-Feldstein $\mathrm{J}$, Boulad F. Sweet syndrome in patients with Fanconi anaemia: association with extracutaneous manifestations and progression of haematological disease. $\mathrm{Br} J$ Haematol. 2011;154:278-281. [CrossRef]

55. Webber L, Cummins M, Mann R, Shaw L, Ghinai R, Mahon C. Panniculitis in a 3-year-old child with Fanconi anemia-associated bone marrow hypoplasia heralds transformation to acute myeloid leukemia. Pediatr Dermatol. 2019;36:725-727. [CrossRef]

56. Liwak-Muir U, Mamady H, Naas T, et al. Impaired activity of CCAadding enzyme TRNT1 impacts OXPHOS complexes and cellular respiration in SIFD patient-derived fibroblasts. Orphanet J Rare Dis. 2016;11:79. [CrossRef]

57. Yang L, Xue X, Zeng T, et al. Novel biallelic TRNT1 mutations lead to atypical SIFD and multiple immune defects. Genes Dis. 2020;7:128-137. [CrossRef]

58. Papa R, Rusmini M, Volpi S, et al. Next generation sequencing panel in undifferentiated autoinflammatory diseases identifies patients with colchicine-responder recurrent fevers. Rheumatology (Oxford). 2020;59:344-360. [CrossRef]

59. Jordan MB, Allen CE, Weitzman S, Filipovich AH, McClain KL. How I treat hemophagocytic lymphohistiocytosis. Blood. 2011;118:40414052. [CrossRef]

60. Rosado FG, Kim AS. Hemophagocytic lymphohistiocytosis: an update on diagnosis and pathogenesis. Am J Clin Pathol. 2013;139:713-727. [CrossRef]

61. Lawson CD, Ridley AJ. Rho GTPase signaling complexes in cell migration and invasion. J Cell Biol. 2018;217:447-457. [CrossRef]

62. Lam MT, Coppola S, Krumbach OHF, et al. A novel disorder involving dyshematopoiesis, inflammation, and HLH due to aberrant CDC42 function. J Exp Med. 2019;216:2778-2799. [CrossRef]

63. Ter Haar NM, Eijkelboom C, Cantarini L, et al. Clinical characteristics and genetic analyses of 187 patients with undefined autoinflammatory diseases. Ann Rheum Dis. 2019;78:1405-1411. [CrossRef]

64. Hwa V. STAT5B deficiency: Impacts on human growth and immunity. Growth Horm IGF Res. 2016;28:16-20. [CrossRef]

65. Takeuchi O, Kawai T, Sanjo H, et al. TLR6: A novel member of an expanding toll-like receptor family. Gene. 1999;231:59-65. [CrossRef]

66. Feldmann J, Callebaut I, Raposo G, et al. Munc13-4 is essential for cytolytic granules fusion and is mutated in a form of familial hemophagocytic lymphohistiocytosis (FHL3). Cell. 2003;115:461473. [CrossRef]

67. Yu CH, Moecking J, Geyer M, Masters SL. Mechanisms of NLRP1Mediated Autoinflammatory Disease in Humans and Mice. $J \mathrm{Mol}$ Biol. 2018;430:142-152. [CrossRef]

68. Sahin N,Özdemir S,Berdelı A. et al. M1184V mutation in NLRP1: is that polymorphism or pathogenic mutation? 10th Congress of International Society of Systemic Auto-Inflammatory Diseases (ISSAID). Pediatr Rheumatol. 2019;17-18. [CrossRef] 